https://doi.org/10.38129/Ann.Yur.Ist.2020.4.3.73

УДК 347.158+347.151.4(611.013)

\title{
ПРИРОДНЕ ПРАВО ЯК ПІДСТАВА ДЛЯ ПОЗИТИВНОГО ПРАВА НА ЖИТТЯ ${ }^{1}$
}

\author{
ПЕТРО ГУСАК (Львів, Україна) *
}

Право людини на життя гарантує цілий ряд документів - як міжнародних, так і українських: «Загальна декларація прав людини» (10.12.1948; ст. 3), «Конвенція про захист прав людини та основних свобод» (4.11.1950; ст. 2-1)², а також Конституція України, яка в статті 27 стверджує: «Кожна людина має невід'ємне право на життя». Виникає питання: Яке походження цього права? Чи воно лише позитивне ${ }^{3}$ та конвенційне, тобто - результат суспільної угоди чи народного волевиявлення, яке суспільний авторитет (в міжнародному вимірі $\mathrm{OOH}$, а в Україні - Верховна Рада) зафіксував як норму законодавства, і у випадку, коли суспільна угода зміниться, або ж волевиявлення народу (чи народів) вимагатиме заперечення права на життя для окремих груп людей, то законодавчі формулювання, які гарантують право на життя, втратять чинність або зміняться? Якщо б так було насправді, то розмова про право на життя й увесь пафос його відстоювання не вартували б детальнішої уваги, тому що в будь-який момент людство через своїх легітимно обраних представників на національному чи / та міжнародному рівнях могло б його змінити, звузити чи скасувати. У зовсім недавній історії ми маємо яскравий приклад такого правового підходу: саме так розуміли право на життя ті, хто пізніше сів на лаву підсудних знаменитого Нюрнберзького процесу (20.11.1945-1.10.1946). Підсудні,

1 Передрук доповіді на Всеукраїнській конференції «Аборт: Заперечення права на життя» (Київ, 03.12.2005). Текст раніше публікувався в електронному форматі: Режим електронного доступу: christian-psychology.org.ua/psy-individ/4442-prirodne-pravo-yakpdstava-dlya-pozitivnogo-prava-na-zhittya.html. 31-03-2017, 18:52. Стаття актуалізована на замовлення Наукової редакціииної ради АЮІ.

${ }^{2}$ Цей документ ратифіковано 17 липня 1997 р. Верховною Радою України.

3 Позитивним (від лат. розіtит - встановлене) зветься право, джерелом якого є (тільки) волевиявлення ююдей, тобто - сформульоване на тих чи інших правових засадах чинне законодавство. 
яких трибунал в Нюрнберзі визнав винними в тому, що заперечували право на життя цілим групам людей, дискримінуючи їх за етнічними, релігійними та расовими ознаками, не визнали свою вину, мотивуючи тим, що діяли у відповідності 3 чинним законодавством, яке формулював i видавав «легітимний»4 уряд нацистської Німеччини. 3 точки зору правового позитивізму та конвенціоналізму їх неможливо було звинуватити. I все ж суд визнав їх винними. Американський суддя Джексон, який зачитував обвинувальний акт, ствердив, що цих осіб привела на лаву підсудних їхня ненормальна та нелюдська поведінка, яка становить склад злочину, тому що «ми вважаємо злочинною заплановану чи намірену поведінку, яка є хибною як 3 моральної, так із правової точки зору»5. Одним 3 основних звинувачень було звинувачення в «злочинах проти людства», першим серед яких були названі вбивство і винищування (тобто - порушення права на життя), що їх Статут Міжнародного Військового Трибуналу в Нюрнберзі кваліфікував як злочини «незалежно від того, чи [дані акти] були чи не були порушенням чинного законодавства тієї країни, де вони були скоєні» (Charter of International Military Tribunal, article 6) ${ }^{6}$.

Що ж є підставою для права людини на життя, якщо зазіхання на нього завжди є злочином, незалежно від прийнятого на тій чи іншій території чинного законодавства? Підстава для права людини на життя є незрівнянно тривкішою та грунтовнішою, аніж правовий позитивізм та конвенціоналізм: нею $\epsilon$ природне право.

Що ж таке природне право? Полишаючи поза увагою можливі - до речі, часто конвенційні - визначення та інтерпретації природного права, спробую звернутися до його суті. Як говорить сам термін, це право, яке випливає зі самої природи речей, в даному конкретному випадку, коли йдеться про життя людини, це право випливає зі самої природи людини․ Іншими словами: природа людини є підставою та джерелом правових формулювань, які стосуються людини та їі суспільного виміру буття. Якою ж є ця природа, якщо

\footnotetext{
${ }^{4}$ Адольфа Гітлера і його прибічників було обрано шляхом демократичного голосування.

5 The Trial of German Major War Criminals - provides transcripts from the Nuremberg trials, на веб-сторінці http:/ / www.nizkor.org/, Second Day: Wednesday, 21st November, 1945, Part 1 of 8 (переклад та підкреслення мої - П. Г.).

6 Див.: там само, Judgment (30th September, 1946 - 1st October, 1946): The Charter Provisions (переклад та підкреслення мої - П. Г.).

7 Під поняттям «природа» я розумію тут суть, конститутивну структуру людини як цілості, а не тільки іiі біологічну складову - тіло, інстинкти і т. д.
} 
вона є підставою для права людини на життя? I чому серед усіх живих істот якраз на противагу до рослин і тварин - тільки людина має право на життя? Дати відповідь на це питання (і тим самим стати необхідною основою для правових формулювань) можуть:

1. філософська антропологія;

2. емпіричні науки, об'єктом дослідження яких є людина;

3. богослов' я.

Кожне правове формулювання, яке стосується людини, іï життя та гідності, повинно спиратися на результати досліджень цих наук, інакше воно буде безпідставним, голослівним та відносним. (Я обмежуся тут лише до перших двох наукових напрямків - філософської антропології та однієї 3 емпіричних наук - біології людини, точніше ії підрозділу, званого ембріологією).

Базована на самій дійсності, на даності людини філософська антропологія дає нам зрозуміти, що людина, на відміну від інших біологічних істот, є особою, тобто істотою, яка наділена розумом, почуттями та свобідною волею, істотою, що здатна свідомо здійснювати своє буття, «володіти собою» та визначати своє свобідне ставлення до себе та до всього іншого. Через те вона посідає незрівнянну гідність та недоторканні, непорушні права (які, окрім усього іншого, забороняють також трактувати ऑï як засіб для чого-будь). Людина $є$ особою вже тому, що є людиною, що належить до виду homo sapiens sapiens (повторення видового означення sapiens вказує на те, що в роді homo («людина») не існує видів які були б нерозумними, відповідно - не існує індивідуумів роду homo, які не були би особами ${ }^{8}$. Особа настільки радикально відрізняється від всього неособового буття, що неможливо, щоби щось стало особою, що не було нею від початку. Щось або є особою, або нею не є‥ Отже,

8 Людські індивідууми можуть не виявляти специфічно особових здатностей та актів (мислення, свідомість, свобідна воля, любов і т. д.), але у такому випадку вони або ще

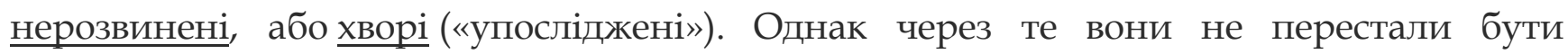
особами, бо ці здатності та акти хоча і є свідченням «актуалізованості» особи, але не $є$ необхідними критеріями особовості. Інакще ми прийдемо до абсурдних висновків, щзо ююдина, котра спить, перебуває в комі чи непритомна, перестала бути особою $і$ втратила свою гідність та недоторканні права. «Неактуалізовані» людські індивідууми є особами на підставі вже того факту, що вони люди. Якщо би вони осягнули певний етап свого розвитку, чи якщо би було можливо усунути штучну перешкоду (хворобу), то особові якості би проявилися.

9 Слід бути дуже уважним у вжитку слова «розвиток»: прихильники матеріалістичного, еволюиіоністського бачення ююдини розуміють «розвиток» як «набуття нових властивостей, 
якщо доросла актуалізована людина є особою, то вона є нею від початку, тобто - від зачаття, і вже від цього моменту їй притаманна специфічно особова гідність та недоторканні основні права - точно такі, які притаманні дорослій людині. Саме тому особа посідає недоторканне право на життя - від початку свого існування і до його природного (біологічного) закінчення.

Що стосується даних біології людини, і зокрема, ембріології (адже основні суперечки ведуться саме стосовно природи людини до іï народження), то сучасна ембріологія говорить нам, що життя людини починається 3 моменту злиття статевих клітин (точніше - з моменту злиття їхніх оболонок, ще до злиття ядер, бо вже з цього моменту статеві клітини починають функціонувати та розвиватися як одне ціле). 3 цього моменту, завдяки неповторному генетичному кодові, починається розвиток нової людини. (Таким чином, сучасна ембріологія спростовує т. зв. «основний біогенетичний закон» Ернста Геккеля, що виражався формулою: «Онтогенез повторює філогенез»10, тобто, що в ембріональному розвитку людина начебто повторює еволюційний розвиток від «амеби» через рибу, амфібію, рептилію і т. д. аж до людини. У світлі досягнень сучасної ембріології це твердження $є$ ненауковою нісенітницею11, побудованою на

яких перед тим зовсім не було». Натомість, сама етимологія та належне розуміння поняття «розвиток» вказують на те, щуо Воно означає «розгортання», «розкриття» Вже наявниху задатках (зачатковіи формі) Властивостей. Нішо не може «розвинутися» в якусь істоту, якщо воно нею перед тим не було, якщуо воно не мало задатків, тобто специиоічних властивостей даної істоти у зачатковій стадіï. (Наприклад, свинячий ембріон ніколи не розвинеться в людину, бо не має для цього задатків, а стане свинею, бо для цього задатки у нього є).

10 Philipp E. Johnson. Darwin on Trial. InterVarsity Press, Downers Grove, Illinois 1993. Pp. 71-72.

11 Улюбленим прикладом, який унаочнює геккелівську теорію, є факт, що на певному етапі розвитку в ембріона наче б то з'являються зяброві щілини. Однак ще до Геккеля було відомо, що ці складки у своїй будові та функціях не відповідають зябрам дорослих риб. Було відомо, що з них розвиваються такі структури, як нижня і верхня щелепи, язикова кістка, гортань, елементи кісток середнього вуха та різноманітні шийні залози і лімфатичні вузли. Тому Райхерт (Reichert) вже у 1836 р. запропонував називати їх «вісцеральними складками». Сьогодні, після досліджень Еріха Блехшмідта (Blechschmidt), відомо, що виникнення цих «вісцеральних», чи «фарингеальних складок» зумовлене ростом мозку, нервового стовбура, серця та кровоносних судин. Швидкий ріст їхніх клітин приводить до утворення складок та до формування передхрящевих структур, («бластемів»), м’язів і нервів. Згідно 3 генетичною програмою, ці тканини призначені для утворення спеціальної структури у шийно- 
нечесності псевдонауковця та фальсифікаціях: Геккель фальшував зображення людських і тваринних ембріонів, щоби їхньою схожістю довести істинність еволюційної теорії Дарвіна $\left.{ }^{12}\right)$. Зигота вже є людиною, а отже - особою, хоча ії специфічно особові здатності та особові акти (такі, як мислення, воління, любов, сміх і т. д.) проявляться далеко пізніше ${ }^{13}$. Всі подальші стадії пренатальної фази онтогенезу людини, всі диференціації тотіпотентних клітин та утворення органів - типово людські. В цьому розвитку не існує якогось «порогу гомінізації», до якого ембріон ще не був би людиною, а після нього - став би 14. Ось як про це говорить відомий німецький ембріолог Еріх Блехшмідт:

«Індивідуальність живої людини зберігається від моменту запліднення, протягом усього розвитку і аж до смерті, змінюється лише фенотип (зовнішній вигляд). Сьогодні цей факт доведений як елементарний принцип біології.

головній частині - щелеп, вушних кісток, жувальних м'язів тощо. Кожна з чотирьох складок є специфічним «матеріалом» для різних структур лицьової частини черепа та шиї. Детальніше про це: Ullrich Henrik. Embryologie und Stammesgeschichte. In: Junker Reinhard, Scherer Siegfried. Evolution. Ein kritisches Lehrbuch. Gießen: Weyel Lehrmittelverlag, 1998. Pp. 187-190.

12 Блехшмідт Еріх. Збереження індивідуальності. Людина - особа від самого початку. Дані ембріології людини. Львів: В-во УКУ, 2003. С. 20-21.

13 Пор.: Andreas Laun. Thesen zur ethischen Bewertung der In-Vitro-Fertilisation (IVF). In: Aktuelle Probleme der Moraltheologie. Wien: Herder, 1992. P. 125.

14 Пор.: Блехшмідт Еріх. Збереження індивідуальності. Людина - особа від самого початку. Дані ембріології ююдини. Львів: В-во УКУ, 2003. С. 46-75. Встановлена українським законодавством вікова межа, до якої офіційно дозволено робити аборт - донедавна це було 28 тижнів, тепер 22 - не має під собою жодної наукової підстави. Не визнавати момент злиття мембран статевих клітин початком життя людини та довільно вважати інші, виокремлені з цілісного процесу пренатального онтогенезу моменти таким початком (такі, як нідація, церебралізація і т. п.) означало би застосовувати модальну логіку з ії формулою: «Давайте приймемо те і те за вихідні умови» до дійсності, яка своєю даністю сама задає вихідні умови і заперечує прийняття довільних вихідних умов. (Модальна логіка має своє значення, скажімо, в комп'ютерних операційних системах чи у визначенні правил гри, тобто - у витворах ююдських рук, але коли ї стосувати до дійсності, яка не є витвором ююдини, то неминуче настане спотворення иієї дійсності). Модальну логіку щодо початку людського життя зазвичай використовують, щоби мати «розв'язані руки» для маніпуляцій з ембріонами (добування стовбурових клітин, досліди, які ведуть до смерті ембріона...). До таких логічних та біоетичних викрутів часто спонукає потужний фінансовий інтерес: де говорить Мамон, там віддані йому «науковці» підлаштовують біоетичні міркування. 
Досліджувати, на якій стадії розвитку з людської зиготи виникає людина, хибно вже в засновку. Адже людина не стає людиною, а є людиною, починаючи від запліднення. Ми говоримо про розвиток людини не тому, що із якогось, спочатку, можливо, неспецифічного нагромадження клітин у процесі розвитку все виразніше виникає людина, а тому, що людина розвивається із уже людської клітини. ... Бути людиною - це не феномен, що випливає 3 онтогенезу, а дійсність, яка є передумовою онтогенезу»15.

Це значить, що людина є людиною на кожній стадії розвитку, а отже повинна мати в незвуженому обсязі всі фундаментальні, невідчужувані права людини незалежно від стадії їі розвитку.

Саме ці наукові дані про природу людини мусять лягти в основу формулювань українського законодавства, яке повинно гарантувати право на життя кожній людині: саме таке формулювання є в ст. 27 Конституції України: «Кожна ююдина має невід'ємне право на життя» (курсив мій - П. Г.). Однак українська правова дійсність є інакшою: Цивільний Кодекс України (який по відношенню до Конституції є «конкретизуючим законом» і тому - керівництвом для дій юристів, відводячи Конституції лише декларативну роль) гарантує право на життя вже не кожній людині, а лише «фізичній особі» (ЦКУ, ст. 281 «Право на життя», ч. 1 і ч. 2), визначаючи пї правоздатність 3 моменту народження (ЦКУ, ст. 25 «Цивільна правоздатність фізичної особи», ч. 2). Таким чином, Цивільний Кодекс України вилучає 3-під дії права на життя людей, які перебувають у лонах своїх матерів, дискримінуючи їх за стадією розвитку ${ }^{16}$. Та сама ст. 281 ЦКУ («Право на життя»), яка в ч. 1 і ч. 2 гарантує фізичній особі право на життя, в ч. 6. дозволяє «штучне переривання вагітності», звужуючи таким чином застосування ст. 27 Конституції України тільки до вже народжених людей. Це суперечить ст. 22 Конституції України, яка наголошує, що «при прийнятті нових законів ... не допускається звуження змісту та обсягу існуючих прав і свобод». Таким чином, всі гарантовані Українською державою права людини - включно з передбаченим законодавством правовим захистом інтересів зачатої, але ще не народженої дитини (ЦКУ, ст. 25 ч. 2: тут маються на увазі майнові та спадкові питання, однак у поле правосильності цієї статті потрапляє і стаття 6 проєкту Закону Украӥни про права пацієнтів, яка мала би запевнити

15 Блехшмідт Еріх. Збереження індивідуальності. Людина - особа від самого початку. Дані ембріологіi людини. Львів: В-во УКУ, 2003. С. 24-25.

16 Стаття 50 «Основ законодавства України про охорону здоров' я» (19.11.1992 р., № 280212) під назвою «Добровільне штучне переривання вагітності» за своєю правосильністю є вторинною по відношенню до Цивільного Кодексу і похідною від нього. 
права дитини на охорону здоров'я від моменту зачаття) - можуть бути перекреслені й заперечені, якщо згідно зі ст. 281 ч. 6 Цивільного Кодексу України цілком легально та безкарно вбити цю людину ще до ії народження ${ }^{17}$. А отже, всі гарантії основних прав і свобод людини в Україні є лицемірством, адже якщо нема гарантій права на життя, якщо нема самого життя, то не може бути мови про всі подальші права, а отже, ратифікація Верховною Радою України «Конвенції про захист прав людини та основних свобод»є лише «реверансом» убік европейської спільноти. Що ж стосується проєкту Закону України про права пацієнтів, який мав би запевнити права дитини на охорону здоров'я від моменту зачаття, то згідно зі знаменитим сталінським висловом: «Нет человека - нет проблемы», навряд чи хтось лікуватиме хвору дитину в материнському лоні (хіба що за дуже великим бажанням матері, яка ще до того ж повинна бути платоспроможною), якщо законодавство дозволяє «перервати вагітність», що у перекладі на нормальну людську мову означає: вбити цю дитину у лоні їі матері. (Так само й захист майнових і спадкових прав зачатої, але ще не народженої дитини є під великим сумнівом, бо якщо матері більше залежатиме не на дитині, а на успадкуванні майна померлого чоловіка, то вона

17 Базований на положеннях ЦКУ Закон України «Про охорону дитинства» в ст. 6 говорить, що «кожна дитина має право на життя 3 моменту визначення іï живонародженою та життєздатною за критеріями Всесвітньої організації охорони здоров'я». «...Згідно 3 локальними медичними нормами народження фіксується відповідними медичними органами в момент відділення життєздатної дитини від організму матері». (Стефанчук Руслан. Право на життя як особисте немайнове право фізичної особи. Режим длектронного доступу: www.lawbook.by.ru/magaz/PravoUkr/0311/27.shtml). Такі формулювання фактично «розв'язують руки» медичному персоналу не тільки для проведення абортів, а й для вбивства дитини під час пологів чи вже після них: вистачить не дати дитині зробити перший вдих і крик, щоб визнати ії нежиттєздатною чи мертвонародженою, і не нести за це жодної відповідальності. А визначення моменту народження як відділення від організму матері дозволяє один із найбільш огидних видів аборту: «аборт частковим народженням», коли при пологах голова дитини залишається в родових шляхах матері, а ії мозок висмоктується вакуум-аспірацією. Такі формулювання ставлять право на життя в залежність від чийогось «визнання», зовнішніх обставин (перебування в лоні матері чи відділення від неї) та від того, що з дитиною станеться опісля - «вижила чи ні». Якщо «не вижила», значить не набула права на життя. (Те саме можна було б сказати й про дорослу вбиту людину: 3 моментом смерті внаслідок вбивства вона втратила право на життя, а отже, злочинець не несе відповідальності). Такі формулювання є цинічними і злочинними, i тому їх потрібно негайно скасувати. 
легально зробить аборт i стане спадкоємицею). Колізію в згаданих формулюваннях Цивільного Кодексу помітно й з того, що якщо ст. 25 ч. 2 ЦКУ обумовлює, що в окремих випадках закон захищає інтереси зачатої, але ще не народженої дитини (йдеться про майнові і спадкові питання), то по-перше, зачата дитина виразно називається тут дитиною (а значить, всі інші норми, які дозволяють «переривання вагітності», фактично дозволяють інфантицид вбивство дітей, а по-друге, якщо ненароджена дитина має «інтереси» (майнові чи спадкові), то вона є «кимсь», хто взагалі може мати інтереси, тобто людиною. Значить, всі норми, які дозволяють та регламентують «переривання вагітності», насправді дозволяють вбивство людини, а тому вони - злочинні 18 .

«Нема нічого нового під сонцем» - казав ще Еклесіаст [Когелет] (Екл. 1,9) і все вертається «на круги своя» (Екл. 1,6). Хоча міжнародна спільнота виразно засуджує гітлеризм і нацизм, однак основні змісти нацистської ідеології, зокрема ії ставлення до цінності людського життя, дискримінація за стадією розвитку, поділ людей на «вартих» і «невартих» жити, продовжують надихати медиків і законодавців. За словами австрійського єпископа Андреаса Ляуна:

«Сьогодні в Центральній Европі багато говорять про голокост, виявляють рішучість «надолужити» минуле і карають найменшу спробу [його] поновити. Але одночасно вбивства тривають далі, тільки іншими засобами, вони стосуються інших груп [людей] та узаконені відповідним законодавством. ... Сучасна держава потрапляє на шлях «субстанційного тоталітаризму», тому що вона таким чином усуває принципи суттєвої рівності всіх та під личиною законності перетворюється в тиранічну державу»19.

На превеликий жаль, в Україні, яка так постраждала від різних геноцидів,

18 Згадані норми входять також в колізію з «обережними» формулюваннями, що їх ми знаходимо у Сімейному Кодексі України (рівному за правосильністю з Цивільним Кодексом): «Правовий статус дитини має особа до досягнення нею повноліття. Малолітньою вважається дитина до досягнення нею чотирнадцяти років» (СКУ, ст. 6 ч. 1 і ч. 2). Тут нічого не говориться про момент народження як початок статусу дитини, а значить, таке формулювання відкрите до тлумачення, що дитина є дитиною від природного початку ії існування, тобто - від зачаття. На таке ж тлумачення наводить і ст. 122 ч. 1 СКУ: «Дитина, яка зачата і (або) народжена у шлюбі, походить від подружжя» (курсив мій - П. Г.).

19 Andreas Laun, Johannes Paul II. Papst des Lebens und Papst der verantwortlichen Elternschaft, Vortrag gehalten im Februar 2000 im Rahmen des Kongresses der Päpstlichen Academia per la vita (www.kirchen.net/bischof/laun); Переклад мій - П. Г.; Пор.: Папа Іван Павло II. Енцикліка Evangelium Vitae. § 20. 
«ідеї фюрера живуть і перемагають». Можливо, автори, які писали Цивільний Кодекс України мали добру волю відповідно до свого розуміння, але дві його статті: ст. 25 ч. 2 ЦКУ, на яку спирається ст. 281 ч. 6 ЦКУ, є безпідставними конвенційними та позитивістськими. Чи не задумуємося ми, що такі формулювання нагадують нацистське законодавство, яке дискримінувало людей за евгенічними, етнічними, расовими чи релігійними ознаками, тільки 3 тією різницею, що згадані статті Цивільного Кодексу України дискримінують людей за стадією їхнього розвитку? Адже визначення поняття фізичної особи та iї правоздатності повинно спиратися на наукові дані про людину взагалі, та на природне право, про що була мова вище. Інакше автори подібних формулювань, та всі ті, хто використовував їх на практиці, посилаючись на «легітимність» своєї діяльності згідно 3 чинним законодавством, можуть потрапити коли-небудь в якості підсудних на Нюрнберзький процес-2, до якого - я маю велику надію - людство колись «дозріє». На такому процесі варто би було посмертно засудити як злочинців проти людства тих, хто легалізував геноцид дітей в лонах матерів, - а також і тих, що ще живуть зараз.

Зі сказаного випливає потреба змін в українському законодавстві та його базованості на природному праві, зокрема в тих законодавчих формулюваннях, які безпосередньо стосуються права зачатої, але ще не народженої дитини на життя, тому що тільки таке право може бути підставою для всіх інших прав людини взагалі. Конкретно: формулювання статті 25 ч. 2 Цивільного Кодексу України повинно звучати так: «Цивільна правоздатність фізичної особи виникає у момент іiі зачаття» ${ }^{20}$. Відповідно, ч. 6 статті 281 ЦКУ, та всі нормативні акти і регулювання, які на неї спираються, втратять чинність. Як

20 Слід нарешті визнати, що народження - це тільки зміна середовища: народитися і вижити може навіть п'ятимісячна дитина, натомість дитина, яку нормально виношують до 9-ти місяців вагітності, згідно 3 дотепер чинним українським законодавством до моменту народження не має права на життя, бо не є «фізичною особою». Українське кримінальне законодавство не передбачає жодного покарання за інфантицид - вбивство дитини в родових шляхах матері персоналом пологового будинку, тому що ще не народжена дитина згідно зі згаданими статтями ЦКУ не є «фізичною особою» та не має права на життя. Медперсонал у такому брутальному випадку цілком безкарно фіксує мертвонародження. Не передбачено також жодної відповідальності для лікаря, який, мотивуючи «медичними показаннями», вчинить аборт після дозволеного законом 22-тижневого терміну вагітності, адже жоден чинний нині український закон не гарантує у ствердний спосіб право на життя дитині до моменту їі народження. 
прецеденти можна взяти до уваги ініціативу Президента США Джорджа Буша про гарантування статусу особи внутрішньоутробному плоду (9.07.2001) та схваленого в Сенаті США законопроєкту, згідно з яким завдання шкоди дитині, яка ще не народилася, вважається таким же злочином, як і злочин проти звичайної людини. Варто взяти до уваги внутрішні ініціативи США, які - в даному випадку - можуть слугувати зразком захисту інтересів своїх громадян.

PhD in Philosophy Petro Gusak (Lviv, Ukraine)

\section{Natural law as the basis for a positive law of life}

The essay is devoted to an extremely topical medical law issue - the establishment of the natural beginning of human life as a formal norm of Ukrainian legislation. Turning to a broad philosophical discourse, the author proves that the beginning of human life cannot be the subject of modal logic. It must be clearly stated in legislation from the moment of conception. Any other interpretations of the issue lead to more or less Nazi visions of the separation of natural and positive law norms.

Key words: man, conception, natural law, positive law, beginning of life, medical law.

Доцент Петр Гусак (Львов, Украина)

Естественное право как основание для позитивного права на жизнь

Очерк посвящен чрезвычайно актуальному вопросу медицинского права установлению естественного начала жизни человека в качестве формальной нормы украинского законодательства. Обращаясь к широкому философскому дискурсу, автор доказывает, что начало жизни человека не может быть предметом модальной логики. Оно должно быть четко зафиксировано в законодательстве с момента зачатия. Любые другие трактовки вопроса ведут к более-менее нацистским интерпретациям разделения норм естественного и позитивного права.

Ключевые слова: человек, зачатие, естественное право, позитивное право, начало жизни, медицинское право.

Доцент Петро Гусак (Львів, Україна)

\section{Природне право як підстава для позитивного права на життя}

Нарис присвячений надзвичайно актуальному питанню медичного права встановленню природного початку життя людини в якості формальної норми українського законодавства. Звертаючись до широкого філософського дискурсу, автор доводить, що початок життя людини не може бути предметом модальної логіки. Його треба чітко зафіксувати в законодавстві - безпосередньо з моменту зачаття. Будь-які інші трактування проблеми призводять до більше чи менше нацистських інтерпретацій, знаменитих диференціацією норм природного і позитивного права. 
Ключові слова: людина, зачаття, природне право, позитивне право, початок життя, медичне право.

* Гусак Петро Романович - кандидат філософських наук, $\mathrm{PhD}$, доцент кафедри філософії філософсько-богословського факультету Українського Католицького Університету.

E-mail: husak@ucu.edu.ua 